\title{
FILSAFAT TAFSIR AL-QURAN DAN BIBEL
}

\author{
Zaimul Am* Sihabudin Noor** \\ *Dosen Magister Pendidikan Agama Islam, Universitas Muhammadiyah Tangerang \\ ** Dosen UIN Syarif Hidayatullah Jakarta
}

\begin{abstract}
Hermeneutic methods are a way to understand and interpret sentences or the contents of a sentence. Hermeneutics examines problems, methods and objectives of interpretation or interpretation. This science helps to determine the true meaning of the text accurately and includes factors such as history, culture, cultural diversity, language, and the distance between the formulation of the contents of the text, the interpreter, the context, and others. Hermeneutics is also seen as a science of aids in formulating rules, principles, and methodologies for interpreting religion, scripture and its relationship with society. The interpretation of the Qur'an has been going on since the early era of Islam, that is, from the time of the Messenger of Allah, the Companions, tabi'in (followers), tabi 'al-tabi'in (followers of followers), and the ulama to the present. Qur'anic science and the Qur'anic exegesis began to develop since the 2 nd century oh hijri and so did the interpretation method of the Qur'an. This study attempts to explain the use of hermeneutic methods as a form of philosophical interpretation in understanding the Qur'an. This study also examines the use of hermeneutics in the West, for example in interpreting the Bible as a comparative analysis.
\end{abstract}

Keywords: Philosophy, Interpretation, Bible.

\section{A. PENDAHULUAN}

Kiranya cukup penting untuk mengkaji latar belakang historis penafsiran Al-Quran. Pada masa awal Islam, satusatunya mufasir Al-Quran adalah Rasulullah saw sendiri dan Rasulullah saw memahami Al-Quran secara umum dan secara terperinci setelah Allah Swt memberikan kepada Nabi saw kemampuan untuk menghapal dan menjelaskan makna ayat-ayat Al-Quran. ${ }^{1}$ Sedangkan para sahabat Nabi saw biasanya memahami AlQuran secara umum dalam hal yang berkaitan dengan makna lahirnya dan

\footnotetext{
${ }^{1}$ Dalam QS al-Qiyamah[75]: 17-19, Allah Swt berfirman, "Sesungguhnya atas tanggungan Kamilah mengumpulkannya (di dadamu) dan (membuatmu pandai) membacanya. Apabila Kami telah selesai membacakannya maka ikutilah bacaannya itu. Kemudian, sesungguhnya atas tanggungan Kamilah penjelasannya."
}

hukum-hukum. Pemahaman Al-Quran secara terperinci yang mencakup makna batinnya dan aspek-aspek rinci makna yang dikandungnya bukanlah hal yang mudah bagi para sahabat Nabi saw jika hanya berpegang kepada pengetahuan mereka tentang bahasa Al-Quran saja. Karena itu, mereka selalu bertanya kepada Rasulullah saw ketika mereka menemukan kesulitan dalam memahami Al-Quran. ${ }^{2}$

Para ulama berbeda pendapat mengenai relatifitas kebenaran pemahaman para sahabat Nabi saw. Ibn Khaldun merupakan pemikir Muslim yang yakin bahwa para sahabat Nabi memiliki pengetahuan yang sempurna mengenai AlQuran karena mereka belajar langsung dari dan mengalami peristiwa-peristiwa turunnya ayat-ayat Al-Quran bersama Nabi

\footnotetext{
${ }^{2}$ Muhammad Husayn al-Dzahabi, Al-Tafsîr wa al-Mufassirûn, (JeddaH: Wazarah Syu'un alIslamiyyah wa al-Da'wah wa al-Irsyad, 2010), 33.
} 
saw. Menurut Ibn Khaldun, Al-Quran diturunkan dalam bahasa Arab dan tentulah para sahabat Nabi saw memahami betul makna kata-kata dalam Al-Quran dalam bentuk kosakata maupun susunannya di dalam kalimat. Tetapi pendapat Ibn Khaldun ini dibantah dengan argumen bahwa meski Al-Quran diturunkan dalam bahasa Arab, namun hal itu bukanlah lantas berarti bahwa semua sahabat Nabi saw memahami makna kata-kata di dalam ayatayat Al-Quran atau, setidak-tidaknya, pasti ada perbedaan tingkat kemampuan mereka dalam memahami Al-Quran. ${ }^{3}$

Dalam tradisi menjelaskan makna ayat-ayat Al-Quran ada dua isu yang mengemuka. Pertama, penjelasan makna ayat-ayat Al-Quran melalui penggunaan kata yang artinya bersinonim atau berdekatan dengan kata yang ada di dalam ayat Al-Quran (disebut sebagai metode tafsîr). Kedua, penjelasan makna ayat-ayat Al-Quran melalui penggunaan kata yang artinya berbeda jauh dengan kata yang terdapat di dalam Al-Quran namun dipandang tetap memiliki relevansi atau konteks (disebut sebagai metode ta'wîl atau penafsiran metaforik).

Tafsîr secara etimologis berarti menerangkan (al-îdhâh ) atau menjelaskan (al-tabyîn). Tafsîr berasal dari akar kata alfasru yang berarti jelas dan terbuka (alkasyf) atau dapat pula diartikan sebagai mengungkap apa yang tertutup (kasyf almughaththâ). Dengan demikian, tafsîr diartikan sebagai mengungkapkan makna dari kata-kata yang sulit. Kata tafsîr dalam arti ini dapat dirujuk kepada QS alFurqân[25]: 33. ${ }^{4}$ Tetapi yang sangat penting

3 'Umar ibn Khattab diriwayatkan pernah membaca ayat Al-Quran ketika berada di atas mimbar "aw ya'khudzahum 'alâ takhawwuf.." dan dia tidak tahu apa arti kata takhawwuf itu lalu dia bertanya kepada sahabat yang lain dan diperoleh jawaban bahwa takhawwuf (takut) berarti tanaqqush (kekurangan). Lihat Muhammad Husayn al-Dzahabi, Al-Tafsîr wa al-Mufassirûn, 33

${ }^{4}$ QS al-Firqân[25]: 33: “Tidaklah orang-orang kafir itu datang kepadamu (membawa) sesuatu yang ganjil, melainkan Kami datangkan kepadamu suatu yang benar dan yang paling baik penjelasannya." Pada ayat ini, kata ahsanu tafsîran mengandung arti ahsanu bayânan wa tafshîlan (sebaik-baik untuk dikemukakan dalam hal ini adalah pengertian etimologis tafsîr yang meliputi penjelasan inderawi (al-kasyf al-hissî) dan penjelasan mengenai arti kata-kata (al-kasyf 'an al-ma' ânî).

Secara terminologis, para ulama mendefinisikan tafsîr sebagai ilmu yang digunakan untuk memahami Kitab Allah yang diturunkan kepada Nabi Muhammad saw, menjelaskan arti dan mengungkap hukum maupun hikmahnya. ${ }^{6}$ Cukup banyak definisi yang diberikan oleh para ulama terhadap ilmu tafsir. Tetapi berbagai definisi tersebut berada dalam kisaran pandangan bahwa ilmu tafsir adalah ilmu yang membahas tentang maksud firman Allah Swt sejauh yang bisa dipahami oleh umat manusia. Definisi ini meliputi semua yang berkaitan dengan pemahaman arti dan penjelasan maksud dari kata yang terdapat di dalam ayat-ayat Al-Quran.

Yang berkaitan dengan tafsîr namun pada perkembangannya kemudian menjadi berbeda dengan tafsîr adalah ta'wîl. Ta'wîl berasal dari akar kata al-awl yang artinya kembali (al-rujồ). Sedangkan ungkapan awwal al-kalâm aw ta'awwalahu (dia menakwilkan kalimat) mengandung arti dabbarahu (menelaahnya), qaddarahu (mengukurnya) dan fassarahu (menjelaskannya). Sedangkan secara terminologis, kata $t a$ 'wîl memilik sekurangkurangnya dua definisi yang berbeda. Pertama, jika para ulama Salaf menggunakan kata $t a$ 'wîl, yang dimaksud adalah menafsirkan kalimat atau menjelaskan artinya terlepas dari apakah arti tersebut sama atau berbeda dari kata yang tersurat. Dalam konteks ini, kata tafsîr dan ta'wîl bersinonim. Ulama Salaf menjelaskan bahwa kata ta'wîl merupakan esensi yang dimaksud oleh kalimat. Jika kalimat itu berisi perintah, maka tentu artinya adalah esensi perbuatan yang

penjelasan dan uraian). Lihat, Muhammad Husayn al-Dzahabi, 'Ilm al-Tafsîr, Kairo: Dar al-Ma'arif, tanpa tahun), 5 Tafsîr, 5

${ }^{5}$ Muhammad Husayn al-Dzahabi, 'Ilm al-

${ }^{6}$ Jalal al-Din al-Suyuthi, Al-Itqân fî̀ 'Ûlûm alQur'ân, (Kairo: Mushthafa al-Bab al-Halabi, 1935), 174

Tadarus Tarbawy. Vol. 1 No. 1 Jan-Jun 2019. 
diperintahkan itu. Kedua, para ulama terkemudian (ulama Khalaf) mendefinisikan $t a$ 'wîl sebagai memalingkan arti yang tersurat (al-râji $\underline{h}$ ) kepada arti yang tersirat (al-marjûh ) karena adanya dalil yang mengkaitkannya. Karena itu, ta'wîl menjadi bersifat lebih luas dari tafsîr dan dikatakan bahwa tafsîr berhubungan dengan periwayatan (al-riwâyah) sedangkan ta'wîl berhubungan dengan pemikiran (aldirâyah). Abu Nashr al-Qusyayri menyatakan bahwa tafsîr dipandang sebagai mengikuti (al-ittibâ') dan mendengarkan (al-simâ') sedangkan ta'wîl dipandang sebagai deduksi (al-istinbâth). ${ }^{7}$

Di dunia Barat, ilmu yang mengkaji bidang penafsiran adalah hermeneutika. Bidang ilmu ini muncul pada abad ke $15 \mathrm{M}$ sebagai sebuah metodologi historis dan kritik untuk menganalisis teks. Istilah hermeneutika menemukan akarnya pada kata kerja Yunani hermeneuein, yang berarti menafsirkan dan kata benda hermeneia yang berarti penafsiran atau tafsir. Hermeneutika merupakan disiplin ilmu intelektual dan filosofis yang mengkaji hakikat dan teori penafsiran mengenai ungkapan manusia. Kamus Oxford English Dictionary menyebut hermeneutika sebagai cabang ilmu yang mengkaji teori penafsiran khususnya penafsiran kitab suci. ${ }^{8}$

Hermeneutika juga dipandang sebagai kajian mengenai prinsip dan metode yang dengannya sebuah teks di masa lalu ditafsirkan untuk menemukan artinya yang relevan dengan konteks saat ini. Palmer menyatakan bahwa hermeneutika bukan hanya ilmu tentang penafsiran namun juga ilmu tentang pemahaman. Bagi Palmer, disiplin ilmu ini menggabungkan dua teori pemahaman, yakni persoalan apa saja yang terlibat dalam peristiwa memahami sebuah teks, dan persoalan mengenai apakah pemahaman itu sendiri dalam arti yang paling mendasar dan eksistensial. ${ }^{9}$

\footnotetext{
${ }^{7}$ Jalal al-Din al-Suyuthi, Al-Itqân fî̀ 'Ûlûm alQur'ân, 173

8 Shorter Oxford English Dictionary on Historical Principles, Vol. I, New York, 2002, 1231

9 Richard E. Palmer, Hermeneutics: Interpretation Theory in Schleiermacher, Dilthey,
}

\section{B. PEMBAHASAN}

\section{Metode Hermeneutik dalam Tafsir Al-Quran}

Di dalam pemikiran Islam, ada dua hal yang saling berhadapan yaitu tafsîr dan ta'wîl. Karena itu, ada dua genre pendekatan tafsir yang saling berhadapan pula, yakni tafsîr bi al-ma'tsûr dan tafsîr bi al-ra'y. Tafsîr bi al-ma'tsûr dipahami sebagai penafsiran yang mencakup apa yang dijelaskan oleh Al-Quran dan apa yang diriwayatkan dari Nabi saw. dan dari para sahabatnya. ${ }^{10}$ Sedangkan yang berkaitan dengan apa yang diriwayatkan dari tabi'in, ada perbedaan pendapat para ulama. Sebagian ulama memandang periwayatan dari tabi'in ini sebagai bagian dari tafsîr bi al-ma'tsûr sedangkan sebagian lainnya memasukkannya ke dalam kategori tafsîr bi al-ra'y. Tafsîr bi al-ra'y didefinisikan sebagai penafsiran Al-Quran dengan menggunakan pemikiran kreatif (alijtihâd) dan berpedoman kepada alat atau kaidah-kaidah yang dibutuhkan oleh mufasir. $^{11}$

Heidegger, and Gadamer, (North Western University Press, Evanston, 1969), 4.

${ }^{10}$ Nur al-Din Atar, 'Ulûm al-Qur'ân al-Karîm, (Damaskus: Mathba'ah al-Shubul), 1993, 74

11 Ada perbedaan pendapat para ulama mengenai boleh atau tidaknya menggunakan ijtihad dalam menafsirkan ayat-ayatAl-Quran. Sebagian ulama memandang penafsiran Al-Quran dengan pendapat pribadi (al-ra'y atau ijtihad) tidak diperbolehkan. Kelompok ulama ini memasukkan tafsîr bi al-ra'y ke dalam kategori berpendapat mengenai Allah tanpa dasar ilmu dan hal ini diharamkan. Mereka juga mengutip hadis dari Jundub bahwa Nabi saw bersabda, "Barangsiapa menggunakan pendapat pribadinya mengenai AlQuran maka dia adalah orang yang bersalah meskipun pendapatnya itu benar. Sedangkan kelompok ulama yang memperbolehkan penggunaan pendapat pribadi (tafsîr bi al-ra'y atau ijtihad) menyatakan bahwa Al-Quran banyak berisi ayat yang memerintahkan perenungan atas makna ayatayat Al-Quran bahkan mencela orang-orang yang tidak mau merenungkannya. Mereka juga menyatakan bahwa jika penggunaan tafsîr bi al-ra'y diharamkan maka tentu ijtihad harus diharamkan pula. Selain itu, mereka merujuk kepada fakta bahwa para sahabat Nabi saw sama-sama membaca AlQuran namun berbeda pendapat mengenai penafsirannya. Jika tafsîr bi al-ra'y diharamkan,

Tadarus Tarbawy. Vol. 1 No. 1 Jan - Jun 2019. 
Al-Kindi, al-Farabi, Ibn Sina dan Ibn Rusyd adalah para filsuf Muslim yang sering menggunakan tafsîr bi al-ra'y dan metode $t a$ 'wîl. Hal ini berkaitan erat dengan upaya mereka untuk mengintegrasikan filsafat Yunani dengan ajaran Islam. AlKindi merupakan filsuf Muslim pertama yang menggunakan penafsiran metaforik ( $t a$ 'wîl) dalam upayanya menyelaraskan agama dan filsafat. Al-Kindi menafsirkan QS al-Rahmân[55]: 6:"Dan tumbuhtumbuhan dan pohon-pohonan keduaduanya tunduk kepada Nya," dengan menyebutkan berbagai arti dari kata sujud (sajdah), yaitu 1) sujud dalam salat, 2) patuh, 3) perubahan dari yang tidak sempurna menuju kesempurnaan, dan 4) mematuhi perintah dari seseorang.Arti keempatlah yang berlaku bagi sujudnya bintang-bintang. Jisim-jisim langit digerakkan dan menjadi sebab bagi kehidupan di alam yang fana. Gerakan jisim-jisim langit itu disebutnya sebagai sujud dalam arti bahwa jisim-jisim tersebut tunduk atau patuh kepada Tuhan. ${ }^{12}$

Dalam konteks penafsiran Al-Quran, Al-Farabi menyatakan bahwa sebagian ajaran agama bersifat tradisional (alsam'iyyât) yakni hal-hal yang tidak dapat dibuktikan oleh akal. Bagi al-Farabi, ayatayat Al-Quran yang menyebutkan al-Law al-Qalam dan sebagainya tidak harus dipahami secara harfiah sebab kata alQalam bukanlah alat untuk menulis dan alLawh bukan pula sebuah halaman tempat mencatatkan berbagai ucapan. Keduanya adalah simbol bagi ketepatan dan preservasi. Al-Quran juga sarat dengan uraian mengenai hari kiamat, hari perhitungan, surga dan neraka. Meski alFarabi sepenuhnya mengakui adanya surga dan neraka, namun dia mereduksinya ke dalam hal-hal yang bersifat spiritual yang tidak ada kaitannya dengan raga. Menurut al-Farabi, adalah ruh dan bukan raga yang

tentu para sahabat tidak akan menggunakannya. Untuk penjelasan ini lihat, Nur al-Din Atar, 'Ulûm al-Qur'ân al-Karîm, 85-86

${ }^{12}$ M.M. Sharif, History of Muslim Philosophy, (Wiesbaden: Otto Harrassowitz, 1963), 427 merasakan kesenangan atau rasa sakit, bahagia atau menderita. ${ }^{13}$

Seperti halnya al-Farabi, Ibn Sina juga menggunakan metode hermeneutik dalam memahami ayat-ayat Al-Quran tentang hari kiamat. Salah satu term yang disebutkan dalam Al-Quran bagi hari kiamat adalah $a l-m a ' a ̂ d$. Menurut Ibn Sina, kata al-ma' $\hat{d} d$ mengandung arti kembalinya ruh ke alam yang menjadi sumbernya dan yang pernah ditinggalkannya selama ia menyatu dengan raga untuk sementara waktu. ${ }^{14}$

Bagi Ibn Sina, yang dimaksud dengan kebangkitan di hari kiamat hanyalah kebangkitan ruh saja dan bukan kebangkitan jasmani. Sekiranya ayat-ayat Al-Quran memberikan kesan adanya kebangkitan jasmani, hal ini harus dipahami dalam dua macam konteks. Pertama, agama disampaikan kepada kaum awam dengan bahasa yang lebih mudah dipahami oleh mereka yang memang tidak terbiasa dengan istilah kiasan atau analogi. Al-Quran sendiri, menurut Ibn Sina, tidak memberikan isyarat mengenai hal penting ini dan tidak menjelaskan secara terperinci kemungkinan kebangkitan ruh dan jasad. Tetapi pada sebagiannya menggunakan metafora yang bersifat fisik dan pada sebagian yang lain bersifat sangat umum dan tidak ada batasan maupun penjelasannya. Kedua, manusia bukanlah manusia dalam artian materi atau fisiknya namun dalam artian bentuk (shûrah, form, rûh) yang ada di dalam materinya. Perbuatan-perbuatan manusia muncul karena adanya bentuk di dalam materinya. Jika dinyatakan bahwa bentuk itu tidak dapat lepas dari materi, lalu bentuk itu musnah dan materinya kembali menjadi tanah atau unsur lain, musnahlah esensi manusia. Jika kemudian diciptakan pada materi ini bentuk manusia yang baru, tentu

\footnotetext{
${ }^{13}$ Al-Farabi, Arâ' Ahl al-Madînah al-Fâdhilah, (Beirut: Dar al-Masyriq, 1986), 67

${ }^{14}$ Salim Mursyan, Al-Jânib al-Ilâhî 'inda Ibn Sînâ, (Beirut: Dar Qutaybah, 1992), 316
} 
yang akan muncul adalah manusia yang lain, bukan manusia sebelumnya. ${ }^{15}$

Menurut Ibn Sina, agama sering membuat metafora yang bersifat fisik atau inderawi dalam hal kebangkitan di hari kiamat ini agar lebih mudah dipahami oleh kaum awam. Para ulama, dalam rangka memberikan motivasi dan peringatan kepada umat, terpaksa menyatakan bahwa kebahagiaan di akhirat dapat dirasakan secara fisik demikian pula kesengsaraannya. ${ }^{16}$

Ibn Rusyd menyatakan bahwa penggunaan metafora yang bersifat fisik mengenai kebangkitan di hari kiamat (al$m a \cdot \hat{a} d$ ) lebih mudah dipahami daripada metafora yang bersifat spiritual (rûhâniyyah). Ibn Rusyd kemudian mengutip firman Allah dalam hadis qudsi, "Telah Kusediakan bagi hamba-hamba-Ku yang saleh apa yang belum pernah dilihat mata, didengar telinga atau terlintas di dalam hati manusia," dan pendapat Ibn Abbas ra bahwa di akhirat tidak ada sesuatupun yang berasal dari dunia kecuali sebatas nama-nama. ${ }^{17}$

Penafsiran di atas, yang berimplikasi penolakan terhadap kemungkinan adanya kebangkitan jasmani, dibantah oleh para ulama termasuk al-Ghazali. Al-Ghazali memandang pengingkaran kebangkitan jasmani, kenikmatan fisik di surga, dan penderitaan fisik di neraka bertentangan dengan apa yang dijelaskan Al-Quran mengenai keduanya dan sekaligus pula bertentangan dengan prinsip ajaran agama Islam. ${ }^{18} \mathrm{Al}$-Ghazali juga menolak argumen para filsuf Muslim yang menyatakan bahwa apa yang disampaikan Al-Quran merupakan perumpamaan (metafora) agar lebih mudah dipahami oleh kaum awam. Contohnya adalah ayat-ayat antropomorfistik (tasybîh) dan Allah Mahasuci dari apa yang dipahami oleh kaum awam. Al-Ghazali

\footnotetext{
${ }^{15}$ Ibn Sina, Risâlah al-Adhhawiyyah fî amr alma 'âd, Teheran: Syams al-Din Tabrizi, 1382, 44

${ }^{16}$ Ibn Sina, Risâlah al-Adhhawiyyah fî amr alma'âd, 97

17 Ibn Rusyd, Tahâfut al-Tahâfut, (Kairo: Dar al-Ma’arif, 1963), 870

18 Al-Ghazali, Tahâfut al-Falâsifah, tahkik Sulayman Dunya, (Beirut: Dar al-Ma'arif, 1972), 287
}

Tadarus Tarbawy. Vol. 1 No. 1 Jan-Jun 2019. mengemukakan dua argumen untuk menolak pendapat para filsuf Muslim itu. Pertama, kata-kata yang terdapat di dalam ayat-ayat antropomorfistik (al-tasybîh) harus dipahami dengan menggunakan penafsiran metaforik ( $t a$ 'wîl) berdasarkan tradisi Arab dalam hal penggunaan kata kiasan (al-isti'ârah). Sedangkan mengenai sifat-sifat surga dan neraka dengan berbagai uraiannya sudah sangat jelas dan tidak membutuhkan ta'wîl. Kedua, argumenargumen rasional membuktikan kemustahilan tempat, arah, bentuk, tangan, mata, dan perpindahan tempat bagi Allah Swt. Dengan demikian, ayat-ayat antropomorfistik seperti ini harus ditafsirkan dengan menggunakan argumenargumen rasional. Sedangkan apa yang dijanjikan Allah di akhirat bukanlah perkara yang mustahil bagi kekuasaan Allah. Karena itu, ayat-ayat Al-Quran mengenai hal ini dapat dipahami secara harfiah. ${ }^{19}$

Ibn Taymiyyah membantah pandangan para filsuf Muslim mengenai kemungkinan kebangkitan di hari kiamat hanya kebangkitan ruh saja dengan menggunakan dua macam argumen, yakni argumen tekstual (al-naqliyyah) dan argumen rasional (al- 'aqliyyah).

Pertama, argumen tekstual meliputi konvensi para penganut agama samawi mengenai adanya kehidupan setelah kematian dimana amal perbuatan seseorang selama hidupnya di dunia diperhitungkan. Kedua, argumen rasional yakni adanya kesadaran bahwa di balik kehidupan ini ada kehidupan lain untuk menegakkan keadilan yang tidak ditegakkan dalam kehidupan di dunia. Di dalam kehidupan lain itu setiap manusia beroleh pembalasan atas amal perbuatannya selama di dunia, jika baik maka baik dan jika buruk maka buruk. ${ }^{20} \mathrm{Ibn}$ Taymiyyah juga mengutip QS al-Rum[30]: $27^{21}$ dan menyatakan bahwa Allah

\footnotetext{
${ }^{19}$ Al-Ghazali, Tahâfut al-Falâsifah, tahkik Sulayman Dunya, 292-293

${ }^{20}$ Muhammad Harbi, , Ibn Taymiyyah wa Mawqifuhu min Ahamm al-Firaq wa al-Diyânât fî 'Ashrih, (Beirut: 'Alam al-Kutub, 1987), 315

${ }^{21}$ QS al-Rum[30]: 27: "Dan Dialah yang menciptakan (manusia) dari permulaan, kemudian mengembalikan (menghidupkan)nya kembali, dan
} 
menggunakan kata al-nasy'ah al-ûlâ (penciptaan pertama) untuk menunjukkan adanya kebangkitan jasmani di hari kiamat. Ibn Taymiyyah bermaksud menyatakan bahwa mengapa para filsuf Muslim itu mengingkari kebangkitan jasmani di hari kiamat? Padahal Allah Swt telah menyampaikan bahwa manusia akan dibangkitkan di hari kiamat untuk perhitungan amal perbuatan. Hal ini tentu tidaklah sulit bagi Allah yang telah menciptakan manusia dari ketiadaan ( $\min$ al-'adam) dan membangkitkannya dalam kehidupan kedua adalah lebih mudah daripada menciptakannya pertama kali dari ketiadaan. $^{22}$

Dari uraian di atas, muncul dua macam persoalan. Pertama, penggunaan metode hermeneutik dalam menafsirkan ayat-ayat Al-Quran telah menciptakan dua versi pemahaman yang saling bertolak belakang dimana versi yang satu menyatakan kebangkitan di hari kiamat hanyalah kebangkitan ruh saja sedangkan versi yang lain menolaknya dengan menyatakan bahwa kebangkitan di hari kiamat akan meliputi kebangkitan jasmani dan ruhani. Kedua, faktor yang menyebabkan perbedaan ini dapat dilacak pada polemik penggunaan metode hermeneutik dalam memahami ayat-ayat Al-Quran. Perbedaan pendapat pada bagian ini juga menciptakan dua versi pemahaman, yakni ada yang memungkinkan penggunaan metode hermeneutik dan ada yang menolaknya. Elaborasi terhadap kedua versi ini dapat membantu untuk mengetahui versi mana yang lebih dekat kepada kebenaran.

\section{Polemik Metode Hermeneutik Dalam Tafsir Al-Quran}

Dalam kajian tafsir Al-Quran, ada kontroversi mengenai penggunaan metode hermeneutik ( $t a$ 'wîl) dalam memahami arti

menghidupkan kembali itu adalah lebih mudah bagiNya. Dan bagi-Nyalah sifat yang Maha Tinggi di langit dan di bumi; dan Dialah Yang Maha Perkasa lagi Maha Bijaksana."

22 Muhammad Harbi, Ibn Taymiyyah wa Mawqifuhu min Ahamm al-Firaq wa al-Diyânât fî̀ 'Ashrih, 314

Tadarus Tarbawy. Vol. 1 No. 1 Jan - Jun 2019. atau makna kata-kata di dalam ayat-ayat tertentu Al-Quran. Kontroversi ini tercermin dalam dua hal. Pertama, dalam mendefinisikan metode hermeneutik (ta'wîl) itu sendiri. Kedua, implikasi pendefinisian metode hermeneutik ( $t a$ 'wîl) berupa penerapanya dalam memaknai katakata yang ada di dalam ayat-ayat Al-Quran maupun maksudnya.

Sebagaimana telah diuraikan di atas, para ulama Salaf memahami ta'wîl sebagai bersinonim dengan tafsîr. Ibn Jarir alThabari memahami ta'wîl dalam pengertian menafsirkan kata-kata atau menjelaskannya. Karena itu di dalam tafsirnya, al-Thabari acap menyatakan pendapat mengenai ta'wîl firman Allah seperti ini (al-qawl fi ta'wîl qawlihi Ta'âlâ) atau para ahli ta'wîl berbeda pendapat mengenai ayat ini (ikhtalaf ahl al-ta'wîl fì hâdzih al-âyah). Yang dimaksudkan oleh al-Thabari adalah tafsîr. ${ }^{23}$ Dalam pandangan kaum Salaf, ta'wîl hanya mencakup tiga macam ruang lingkup. Pertama, ta'wîl kata (ta'wîl alkalâm) yang berarti mengembalikan kata kepada maksud si pembicara atau mengembalikan arti kata kepada esensinya yakni makna atau maksud kata itu. Ta'wîl ini dibagi ke dalam dua kategori, ta'wîl alinsyâ' dan ta'wîl ikhbâr. Kedua, salah satu bagian dari ta'wîl insyâ' adalah ta'wîl alamr (ta'wil perintah) yang mengandung arti perbuatan yang diperintahkan itu sendiri. Ketiga, Ta'wîl ikhbâr (ta'wil kabar) adalah esensi dari kabar yang disampaikan. ${ }^{24}$ Penggunaan para ulama Salaf atas ta'wîl ini tidak beranjak jauh dari makna kata yang tersurat. Dengan kata lain, kata ta' wîl masih dipandang sebagai bersinonim dengan kata tafsîr.

Para filsuf Muslim dan para ulama Khalaf pada umumnya mengembangkan terminologi ta'wîl yang berbeda dengan para ulama Salaf. Ta'wîl didefinisikan sebagai memalingkan kata dari arti yang

\footnotetext{
${ }^{23}$ Mannâ' al-Qaththan, Mabâhits fì 'Ulûm alQur'ân, (Kairo: Maktabah Wahbah, n.d), 317

${ }^{24}$ Mannâ' al-Qaththan, Mabâhits fî̀ 'Ulûm alQur'ân, 318
} 
tersurat kepada arti yang tersirat karena ada dalil yang mengkaitkannya. ${ }^{25}$

Kontroversi antara ulama Salaf dan ulama Khalaf termasuk pula para filsuf Muslim mengenai penggunaan metode ta'wîl dalam menafsirkan ayat-ayat AlQuran tercermin dalam paparan berikut ini. Pertama, bahwa tafsîr merujuk kepada periwayatan (riwâyah) sedangkan ta'wîl merujuk kepada pemikiran (dirâyah). Kedua, tafsîr merupakan pengungkapan dan penjelasan. Pengungkapan dan penjelasan maksud Allah haruslah dengan merujuk kepada periwayatan yang sahih dari Nabi saw atau dari para sahabat Nabi saw yang menyaksikan turunnya wahyu Al-Quran. Mereka adalah orang-orang yang mengetahui berbagai peristiwa yang berkaitan dengan turunnya wahyu AlQuran, berinteraksi bersama Nabi saw dalam keseharian mereka dan selalu bertanya kepada Nabi saw mengenai berbagai kesulitan dalam memahami arti ayat-ayat Al-Quran. Ketiga, fokus ta'wîl

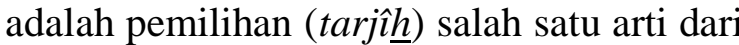
berbagai kemungkinan arti yang dikandung oleh suatu kata dengan menggunakan argumen (dalîl). Pemilihan (tarjîh $\underline{\text { ) ini }}$ didasarkan atas pemikiran kreatif (ijtihâd) yang mengacu kepada pengetahuan tentang sinonim kata dan berbagai artinya dalam bahasa Arab, penggunaannya sesuai konteks, pengetahuan mengenai kaidahkaidah bahasa Arab dan mendeduksikan arti kata yang terdapat di dalam ayat-ayat AlQuran. ${ }^{26}$

Al-Ghazali menolak definisi ta'wîl sebagai mengubah kata dari makna tersurat kepada makna tersirat karena adanya dalil (dalâlah) yang mewajibkannya. Menurut al-Ghazali, ta'wîl yang benar adalah ta'wîl yang bersesuaian dengan apa yang ditunjukkan oleh teks (nushûsh) Al-Quran dan Sunnah Rasulullah saw. Menurut alGhazali, apa yang disampaikan Al-Quran adalah benar sebab yang batil tidak akan disampaikan oleh Al-Quran. Orang-orang

\footnotetext{
${ }^{25}$ Mannâ' al-Qaththan, Mabâhits fî̀ 'Ulûm alQur'ân, 318

${ }^{26}$ Muhammad Husayn al-Dzahabi, 'Ilm alTafsîr, 8
}

Tadarus Tarbawy. Vol. 1 No. 1 Jan-Jun 2019. yang melakukan ta'wîl (ash $\underline{h a} b$ al-ta'wîl) telah terjerumus ke dalam dua macam larangan. Pertama, kita tidak boleh menetapkan sesuatu dari arti ayat Al-Quran dan Sunnah Rasulullah saw kecuali jika kita sudah membahasnya secara panjang lebar untuk memungkinkan hal itu berdasarkan akal. Menurut mereka, akal menunjukkan kebenaran pendapat mereka dan mereka melakukan ta'wîl bahkan dengan melanggar apa yang dilarang. Kedua, hati tidak dapat memutuskan sesuatu yang diyakininya dari apa yang disampaikan oleh Rasulullah saw. jika tidak percaya bahwa makna lahirlah yang dimaksudkan. Banyak ta'wîl yang kacau (al-ta'wîlât mudhtharabah). Akibatnya adalah menjauhkan Al-Quran dan Sunnah sebagai dalil atau petunjuk mengenai apa yang disampaikan Allah kepada para hamba-Nya. Misi utama nabi adalah menyampaikan kabar dan Al-Quran adalah kabar besar. ${ }^{27}$

Al-Ghazali juga menyatakan bahwa para pelaku ta'wîl menyebutkan ayat-ayat Al-Quran, dan Sunnah Rasulullah saw hanya untuk keyakinan (al-I'tiqâd) belaka dan tidak dijadikan pedoman (al-i'timad). Jika teks tersebut bersejalan dengan argumen rasional, mereka jadikan sebagai dalil. Namun jika berbeda atau bertentangan, mereka lakukan ta'wîl atasnya.

Menurut al-Ghazali, dengan cara seperti itu, kata ta'wîl telah digunakan di luar maknanya yang orisinal. Sebab ta'wîl yang benar dalam Al-Quran dan Sunnah Rasulullah adalah kebenaran atau hakikat (al-hiaqîah) yang menjadi sumber rujukan kajian dan bukanlah memalingkan arti dari kata yang tersurat sebagaimana dipahami oleh orang-orang yang menyimpang dari teks agama (al-nushûsh). ${ }^{28}$

\section{Metode Hermeneutik dalam Tafsir Bibel}

Hermeneutika modern berawal dari upaya merumuskan prinsip penafsiran

27 Al-Ghazali, Qânûn fi al-Ta'wîl, dita'liq dan ditahkik oleh Mahmud Bejou, (Kairo: Dar al-Salam, 1993), 7-8 28Al-Ghazali, Qânûn fi al-Ta'wîl, 8 
dengan kesadaran yang semakin berkembang bahwa kitab suci sesungguhnya merupakan dokumen historis yang di dalamnya kebenaran-kebenaran tekstual dan maknanya berkaitan sangat erat dengan ruang dan waktu kitab suci itu diturunkan. Pada mulanya istilah hermenutika ditempatkan di dalam lingkup yang suci. ${ }^{29}$

Pesan Tuhan hanya dapat dipahami melalui ungkapannya sendiri, yang diterima dengan ketidakpastian tersurat mengenai kebenaran dan kesalahannya. Ketaksaan pesan ini merupakan irasionalitas, semacam ketidaksadaran yang menimpa penerimanya. Hanya orang yang memiliki metode penafsiran rasional-yakni para penafsir hermeneutik generasi pertamayang mungkin menjadi sumber kebenaran atau kesalahan sebuah pernyataan. ${ }^{30}$

Hermeneutika berasal dari kata kerja hermeneuein dan kata benda hermeneia yang merujuk kepada pesan Dewa Hermes dan menjadi sumber asal kata tersebut. Hermes dikaitkan dengan fungsi pentransmutasi-an apa yang berada di luar jangkauan pemahaman manusia ke dalam sebuah bentuk yang dapat dipahami oleh akal manusia. Proses memahami pesan yang dibawa yang dikaitkan dengan Hermes ini secara implisit terangkum di dalam tiga arah dasar makna kata kerja hermeneuein dan kata benda hermeneia dalam penggunaan di zaman kuno. Ketiga arah ini, sebagaimana tercermin dalam bentuk kata kerja hermeneuein adalah berkata, menjelaskan dan menerjemahkan. Ketiga arti ini dapat diungkapkan melalui kata kerja menafsirkan meskipun masingmasignya memiliki makna penafsiran yang independen dan signiifikan. Dalam konteks ini, penafsiran dapat merujuk kepada tiga macam isu: bacaan lisan, penjelasan dan penerjemahan.

Di Barat, ada enam pola penggunaan penafsiran hermeneutik. Pertama, penafsiran Bibel. Kedua, metodologi

\footnotetext{
${ }^{29}$ Jean Grondin, Introduction to Philosophical
} Hermeneutics, (New Haven: Yale University Press, 1994), 21.

$$
{ }^{30} \text { Ibid., p. } 22
$$

Tadarus Tarbawy. Vol. 1 No. 1 Jan-Jun 2019. filologis. Ketiga, ilmu tentang pemahaman linguistik. Keempat, dasar metodologis ilmu-ilmu kemanusiaan. Kelima, fenomenologi wujud. Keenam, sistem penafsiran simbol-simbol. ${ }^{31}$

Pertama, penafsiran Bibel yang di dalam formulasi awalnya membedakan penafsiran (commentary atau exegesis) dengan kaidah, metode atau teori yang membentuknya (hermeneutika). Tetapi, penggunaan umum konsep penafsiran Bibel dalam bahasa Inggris merujuk kepada hermeneutika Bibel yakni menjelaskan atau menafsirkan. Hasil kajian Gerhard Ebeling terhadap hermeneutika Luther menunjukkan baik metode, penjelasan, teori maupun penafsiran Bibel tercakup di dalam apa yang dapat disebut sebagai hermeneutika Luther. Hal ini kemudian memperluas konsep hermeneutika sehingga mencakup semua teori penafsiran, baik yang bersifat implisit dan eksplisit, maupun yang merujuk kembali kepada berbagai praktik penafsiran Kitab Perjanjian Lama.

Kedua, filologi yang berkembang pada abad ke 18 bersamaan dengan munculnya mazhab rasionalisme dalam filsafat. Pendekatan historis-kritis terhadap kajian Bibel bersama dengan berbagai mazhab historis tradisional dan gramatikal dalam penafsiran Bibel menegaskan bahwa berbagai metode interpretatif di dalam kajian Bibel dapat pula diterapkan terhadap teks yang lain. ${ }^{32}$

Ketiga, yang berkaitan erat dengan berbagai bentuk hermeneutika dan bertitik tolak padanya adalah ilmu hermeneutika yang digagas Schleiermacher. Konsepsinya mengenai penafsiran berupaya untuk mengatasi kaidah dan berbagai prosedur agar bisa menciptakan sebuah ilmu hermeneutika koheren yang menjelaskan berbagai syarat untuk memahami dialog. Konsepsi umum hermeneutika ini dicatat oleh Palmer sebagai yang menandai awal hermeneutika nondisipliner yang sangat penting bagi kajian bidang terkait. Untuk pertama kalinya,

\footnotetext{
${ }^{31}$ Richard E. Palmer, Hermeneutics, (Evanston: Northwestern University Press, 1969), 33

${ }^{32}$ Richard E. Palmer, Hermeneutics, 34
} 
hermeneutika menjadi kajian tentang pemahaman itu sendiri. ${ }^{33}$

Keempat, upaya memperluas hermeneutika sebagai dasar bagi semua ilmu manusia, apakah sebagai kajian sastera, hukum maupun berbagai jenis aktifitas lainnya. Menafsirkan semua aktifitas manusia butuh pemahaman historis yang berbeda dari ilmu-ilmu alam kuantitatif. Penafsiran butuh keterlibatan di dalam objek kajian melalui pengetahuan personal tentang apa sebenarnya seorang manusia itu. Yang dibutuhkan ilmu-ilmu kemanusiaan adalah kritik terhadap "akal historis"yang kira-kira setara dengan kritik Kant terhadap akal murni bagi ilmu-ilmu alam (natural sciences). Upaya Dilthey mencari dasar humanistik yang cocok bagi Geisteswissenschaften telah menciptakan penafsiran yang menjadi tafsir atas objek yang selalu bersifat historis. ${ }^{34}$

Kelima, kajian fenomenologis sebagai sebuah hermeneutika Dasein yang digagas Martin Heidegger. ${ }^{35}$ Karya ini menandai transisi besar bukan hanya dalam praktik (metode) hermeneutik namun juga dalam objek analisisnya. Heidegger mengalihkan perhatiannya kepada penguraian mengenai Wujud itu sendiri. Ketika ia beralih kepada analisis fenomenologisnya, model dasar Dasein menjadi pemahaman dan penafsiran. Implikasinya adalah bahwa hermeneutika berkembang hingga mencakup ontologi dan epistemologi pada tataran kewajiban manusia untuk memahami sebuah objek.

Keenam, bagian akhir dari daftar singkat definisi modern mengenai harmeneutika secara khusus dapat ditemukan pada sistem penafsiran Paul Ricoure yang menaruh perhatian terhadap simbol-simbol. Dia memilih sebuah definisi mengenai penafsiran tekstual sebagai hermeneutika sentral. Menurut Ricoure, melalui hermeneutika, orang akan selalu memahami teori kaidah-kaidah yang ada pada sebuah penafsiran-yakni penafsiran

\footnotetext{
${ }^{33}$ Richard E. Palmer, Hermeneutics, 38

${ }^{34}$ Richard E. Palmer, Hermeneutics, 44

${ }^{35}$ Martin Heidegger, Being and Time, trans. John Macquarrie and Edward Robinson (San Francisco: Harper Collins Pub., 1962), 27
}

terhadap sebuah teks khusus, atau kumpulan tanda-tanda yang dapat dianggap sebagai sebuah teks. ${ }^{36}$

Tanda-tanda ini dapat dibagi ke dalam 2 (dua) kategori. Pertama, tanda-tanda yang memiliki satu arti (univocal). Kedua, tandatanda yang memiliki banyak arti (equivocal). Tipe kedua-lah yang menjadi fokus hermeneutika. Tanda-tanda ekuivokal mungkin saja berisi sebuah kesatuan linguistik dengan arti lahir yang sekaligus pula menimbulkan serangkaian arti lain atau arti yang lebih dalam. Ricouer mengajukan dua bentuk hermeneutika yang sangat berbeda. Salah satunya pernah dikemukakan oleh Rudolf Bultman yang ingin melakukan demitologisasi teks Bibel dengan cara menemukan arti yang berada di balik simbol. Cara lainnya adalah dengan menghancurkan simbol melalui sikap hatihati dan keragu-raguan demi menciptakan sebuah sistem baru untuk menafsirkan dunia secara apa adanya. ${ }^{37}$ Dengan kedua pendekatan penafsiran simbol yang saling bertentangan ini, Ricouer menyatakan bahwa tidak ada teori universal mengenai penafsiran karena yang ada hanyalah tafsir yang berbeda dan saling bertentangan satu sama lain. $^{38}$

Kontroversi dalam penafsiran Bibel, seperti yang telah disinyalir Ricouer, dapat dibagi ke dalam 2 (dua) kategori besar. Pertama, yang berkaitan dengan hubungan antara pentingnya memahami karakter para penulis Bibel dengan penafsiran Bibel. Kedua, hubungan antara penafsiran Bibel dengan perkembangan ilmu pengetahuan dan modernitas.

Pada kategori yang pertama, kontroversi terjadi antara Schleiermacher dan Gadamer. Schleiermacher adalah seorang tokoh yang dipandang sebagai bapak hermeneutika zaman modern. Schleiermacher telah mengubah penafsiran tradisional Bibel menjadi sebuah

${ }^{36}$ Paul Ricoeur, Freud and Philosophy. An Essay on Interpretation, trans. Denis Savage (New Haven: Yale University Press, 1970), 8.

\footnotetext{
${ }^{37}$ Richard E. Palmer, Hermeneutics, 44

${ }^{38}$ Ricoeur, Freud and Philosophy, 26-27
} 
hermeneutika umum yang mencakup semua jenis teks. Dalam hal ini, yang dimaksud dengan teks merujuk kepada segala sesuatu, bukan hanya kata-kata yang ditulis namun juga percakapan, pemahaman dan sebagainya.

Dengan menaikkan kajian hermeneutika ke tingkat yang universal, Schleiermacher telah memasukkan hermeneutika ke dalam sebuah dunia pemahaman dan penafsiran yang baru. Yang muncul kemudian adalah sebuah metodologi bagi ilmu-ilmu kemanusiaan. ${ }^{39}$ Schleiermacher membedakan antara membaca sebuah teks dengan dialog dalam percakapan. Pembaca harus memainkan dua peran sekaligus di dalam dialog: peran sebagai penulis dan peran sebagai penerima teks. Hal ini disebutnya sebagai percakapan yang signifikan dan ditekankannya makna penting memahami serangkaian pemikiran di dalam teks seakan-akan sebagai sebuah momen kehidupan yang sedang dijalani. ${ }^{40}$ Pembahasan kemudian beralih kepada metode baru dalam memahami makna teks, dan dalam hal ini Schleiermacher menekankan dua macam aspek penafsiran: penafsiran gramatikal dan penafsiran psikologis.

Metode penafsiran gramatikal meliputi pemahaman teks yang membutuhkan pemahaman terhadap katakata dan bahasa umum. Orang harus mencermati kata-kata dalam hubungannya dengan kalimat, dan konteks kalimat di dalam paragraf, demikian seterusnya hingga pemahaman terhadap teks dapat dicapai dengan akurat. Hal ini kemudian menimbulkan apa yang oleh Schleiermacher dsebut sebagai lingkaran hermeneutika. Menurut Schleiermacher, metode penafsiran gramatikal adalah bahwa kosakata dan sejarah hidup penulis Bibel secara bersama-sama membentuk sebuah keseluruhan yang darinya berbagai

\footnotetext{
${ }^{39}$ Terry Graham. "The Dual Aspect of Hermeneutics.” Studies in Religion. 22(1), 1993, 105

${ }^{40}$ David E. Klemm, Hermeneutical Inquiry: Vol. 1, The Interpretation of Texts, (Atlanta: Scholars Press, 1986), 57
}

tulisannya harus dipahami sebagai sebuah bagian. Schleiermacher menunjukkan bagaimana kajian mengenai sejarah linguistik, berikut budaya dan orangorangnya, menjadi mutlak bagi metode penafsiran gramatikal. Bahasa dibatasi oleh kehidupan orang-orang dan oleh kepentingan yang sama pada suatu masyarakat sehingga menciptakan sebuah genre baru yang mencerminkan sejarah sang penulis Bibel. ${ }^{41}$

Metode penafsiran psikologis telah menimbulkan lebih banyak kontroversi dan kritik terhadap Schleiermacher. Metode penafsiran psikologis ini mencakup langkah masuk ke dalam pemikiran kreatif penulis Bibel yang dikenal juga sebagai konsep tentang niat si penulis. ${ }^{42}$

Menurut Schleiermacher, jawaban terhadap persoalan hermeneutika adalah memahami tujuan individual penulis dalam menulis teks dan arti yang dimaksudkan olehnya. Metode ini sangat bergantung pada teknik intuitif (divinatory technique) yang dapat menjelaskan mengapa kata atau kalimat tertentu digunakan di dalam teks itu. Dengan menggunakan konsep intuisi ini, demikian Schleiermacher selanjutnya, orang dapat menciptakan kembali kepribadian dan situasi yang berhubungan erat dengan para penulis Bibel. Dengan mendorong si penafsir untuk mentransformasi diri menjadi si penulis Bibel, metode intuisi ini akan berupaya memperoleh pemahaman langsung terhadap penulis Bibel itu sebagai individu. Menurut Schleiermacher, seorang mufasir harus akrab dengan kehidupan dan zaman penulis Bibel. Keakraban dengan konteks biografis dan historis penulis Bibel menjadi syarat bagi metode penafsiran psikologis. ${ }^{43}$

Menurut Gadamer, persoalan tafsir psikologis terletak pada keharusan

${ }^{41}$ Schleiermacher, F.D.E. Hermeneutics: The Handwritten Manuscripts, Trans. James Duke and Jack Forstman. Ed. Heinz Kimmerle. (Missoula: Scholars Press, 1977), 113

${ }^{42}$ Dan R. Stiver, The Philosophy of Religious Language, (Oxford: Blackwell Publishers Ltd., 1996), 88

${ }^{43}$ Schleiermacher, F.D.E. Hermeneutics: The Handwritten Manuscripts, 100

Tadarus Tarbawy. Vol. 1 No. 1 Jan-Jun 2019. 
memahami penulis Bibel dalam penafsiran. Bagi Gadamer, mempertimbangkan penulis Bibel dan apa yang menjadi maksudnya dalam menafsirkan teks memang penting dalam hermeneutika. Tetapi yang jauh lebih penting adalah memahami kondisi khusus dimana teks itu ditulis maupun kepada siapa teks itu ditujukan. Gadamer menyatakan bahwa fokus pengkajian bukanlah penulis Bibel dan bagaimana penulis tersebut mengungkapkan gagasan-gagasannya. Tetapi, fokusnya adalah si mufasir dan bagaimana dia memahami gagasan tersebut di dalam pergerakan pemahaman dan penafsiran. ${ }^{44}$

Richard Corliss mengkritik hermeneutika Schleiermacher dengan sebuah contoh yakni seseorang yang datang ke kebaktian gereja yang berbeda dari gereja yang biasa dikunjunginya. Dia telah sering mengikuti kebaktian di gereja dan memahami betul bagian-bagian acara kebaktian. Di gereja sebelumnya, dia mengenal pendeta yang menyampaikan khutbah. Sedangkan di gereja yang baru dikunjunginya ini dia tidak mengenal si pendeta. Menurut Corliss, orang itu akan tetap dapat memahami isi khutbah meskipun dia tidak kenal kepada si pendeta. Corliss yakin bahwa memahami isi khutbah tidak menbutuhkan pengetahuan mengenai kehidupan pribadi pendeta. Hal seperti ini juga berlaku pada Bibel. Orang mungkin saja tidak mengenal penulis Bibel. Namun dia tetap dapat memahami apa yang disampaikan dengan cara memahami tradisi keagamaan yang menjadi latar belakang bagi apa yang ditulis. ${ }^{45}$

Pada kategori yang kedua, yakni hubungan antara penafsiran Bibel dengan perkembangan ilmu pengetahuan dan modernitas. Persoalan mendasar dalam hal ini adalah bahwa Bibel secara tekstual memberi gambaran yang dikesankan sebagai hal yang bertentangan dengan ilmu pengetahuan atau para mufasir Bibel

\footnotetext{
44 Terry Graham. "The Dual Aspect of Hermeneutics", 105-16

45 Richard L.Corliss, "Schleiermacher's Hermeneutic and its Critics." Religious Studies. 29, 1993, 363-379
}

Tadarus Tarbawy. Vol. 1 No. 1 Jan-Jun 2019. menganggap penafsiran harfiah mereka terhadap Bibel sebagai dogma yang memiliki kebenaran mutlak.

Ada kelompok di dalam Kristen yang disebut sebagai para ilmuan penciptaan yang mempertahankan penafsiran harfiah terhadap riwayat penciptaan alam sebagaimana terdapat dalam Kitab Kejadian dan menolak bukti-bukti ilmu pengetahuan. Para tokoh kelompok ini memandang hasil penelitian ilmiah sebagai ancaman terhadap keyakinan keagamaan mereka dan yakin bahwa tidak ada titik temu antara keimanan terhadap Bibel dengan kepercayaan terhadap berbagai teori ilmiah semacam teori evolusi. Selain itu, ada kelompok arus utama Kristan dan Yahudi yang percaya bahwa tidak ada pertentangan antara ajaran Bibel dan teori evolusi. Di antara kedua kelompok ini terdapat kelompok lain, yakni kaum fundamentalis yang berpegang kepada modifikasi penafsiran harfiah dan menerima data ilmiah tentang usia bumi. ${ }^{46}$

Perbedaan perspektif mengenai hubungan antara penafsiran Bibel dan perkembangan ilmu pengetahuan ini dapat dilacak kepada perbedaan dalam memandang Bibel itu sendiri. Pada masamasa awal, Bibel dipandang sebagai firman Tuhan dalam arti sempit, seakan-akan Tuhanlah yang mewahyukan setiap kata yang ada di dalam Bibel. Jika Musa merupakan penulis Kitab Kejadian dan bagian-bagian awalnya menjelaskan berbagai peristiwa yang hanya mungkin dilihat oleh Tuhan, maka harus disimpulkan bahwa Tuhanlah yang mewahyukan Kitab Kejadian sebagaimana adanya. Di sisi lain, para pakar Bibel modern berpendapat bahwa Bibel ditulis berdasarkan ilham dari Tuhan. Bahwa para penulis itu mengumpulkan bahan dan melaksanakan pekerjaan mereka seperti para penulis umumnya. Pada masa sekarang, ada bukti kuat bahwa para penulis Kitab Kejadian menghimpun bahan dari berbagai sumber tertulis dan lisan yang ada ketika itu,

${ }^{46}$ James W, Skehan, Modern Science and the Book of Genesis, (Washington: National Science Teacher Association, 1986), 9 
misalnya mitos penciptaan Babilonia dan kisah Mesopotamia tentang Banjir Besar. ${ }^{47}$

Illustrated Bible Dictionary bahkan menyatakan bahwa konsep penciptaan dalam Kitab Kejadian 1.1-2, 4a merupakan sebuah riwayat kesaksian dari perspektif seorang manusia dan atau perspektif bumi. Ia merupakan riwayat fenomenologis yang didasarkan atas pengalaman umum tentang bagaimana seorang Yahudi kuno akan memandang dunia. Siklus siang dan malam merupakan komponen paling penting dari ciptaan Tuhan dan itulah yang diciptakan pertama kali. Kemudian komponen dasar lainnya, yakni sumber air hujan di langit, diciptakan pada kali yang kedua. Akhirnya bumi dipisahkan dari air untuk menjadi tempat hunian manusia. Cara kerja ini menyatakan bahwa riwayat penciptaan disampaikan melalui istilah-istilah observasional sederhana dan pra-ilmiah sebab orang Yahudi kuno tidak memiliki pengetahuan yang sama dengan pengetahuan masa sekarang tentang langit dan bumi. ${ }^{48}$

Akan tetapi, Lawrence berpendapat bahwa riwayat penciptaan di dalam Kitab Kejadian 1.1-2.3 merupakan periwayatan dari Tuhan karena sangatlah jelas bahwa belum ada manusia yang menyaksikan semua peristiwa ini. Hal ini menimbulkan pertanyaan yang menarik mengenai bagaimana penulis Kitab Kejadian 1.1-2.3 memperoleh periwayatan ini? Namun Lawrence juga menyatakan bahwa riwayat penciptaan ini 'bersumber dari bumi' (earth-centered) dan dilihat dari perspektif seseorang yang berada di bumi. ${ }^{49}$

Persoalan lain yang cukup penting adalah bahwa dalam banyak kasus, para penulis Kitab Kejadian sering mengutip sumber tradisional. Tetapi sayangnya, para penulis ini sudah terbiasa untuk tidak memberitahukan saat mengutip atau menyadur tulisan-tulisan yang paralel

\footnotetext{
${ }^{47}$ James W, Skehan, Modern Science and the Book of Genesis, 12

${ }^{48}$ John R. Robert, Biblical Cosmology: The Implication for Bible Translation, Journal of Translation, Volume 9, Number 2, 2013, 6

${ }^{49}$ John R. Robert, Biblical Cosmology: The Implication for Bible Translation, 7
}

seperti yang terjadi pada Kitab Kejadian 1.1-2, 4a mengenai riwayat penciptaan. Dengan membandingkan teks Kitab Kejadian dengan Hikayat Penciptaan di dalam Enuma Elish, dapat dilihat dengan jelas berbagai persamaan dan perbedaan dari segi pengujarannya. Penemuan batu tulis arkeologis yang mencatat hikayat penciptaan Babilonia telah memperjelas hikayat tersebut dan hubungannya dengan Kitab Kejadian. Enuma Elish merupakan sebuah syair epik yang berisi lebih dari seribu bait dan dicatat pada tujuh lembar batu tulis. Para penulis Kitab Kejadian telah meminjam banyak topik dari Hikayat Babilonia yang berusia lebih tua ini, namun menolak topik-topik yang berisi perspektif teologi yang bertentangan dengan ajaran Kristen. ${ }^{50}$

Stadelman menyatakan pendapatnya mengenai kosmologi yang terdapat di dalam Perjanjian Lama. Menurutnya, konsep modern tentang alam semesta yang tidak terbatas dan bersifat terbuka tidak dikenal di dalam Perjanjian Lama. Sebaliknya, langit dan bumi dipandang terkunci pada lingkaran ufuk untuk mencegah tumpahan air kosmik. Orangorang Yahudi kuno memandang alam semesta berada di atas sebuah struktur tiga jenjang. Bumi dianggap sebagai dataran luas yang sebagiannya merupakan laut dan sebagian lainnya merupakan benua. Bumi dipancang oleh gunung, dialiri sungai, dan ditandai dengan titik-titik danau. Ufuk yang mengitari bumi secara sangat alamiah menimbulkan gagasan di kalangan orang Yahudi kuno mengenai bentuk lingkaran. ${ }^{51}$

Mengenai perbandingan antara penafsiran Al-Quran dan penafsiran Bibel, perlu dijelaskan beberapa pandangan para pakar mengenai hal ini. Ada sebuah lingkaran hermeneutik antara teks kitab suci dan pembacanya, namun lingkaran ini dibentuk oleh objek yang mengatur agama dan metode yang mengatur pemahaman.

\footnotetext{
${ }^{50}$ James W, Skehan, Modern Science and the Book of Genesis, 13

51 Luis I. J, .Stadelmann, The Hebrew conception of the world: A philological and literary study, (Rome: Pontifical Biblical Institute, 1970), 43
} 
Dalam hal ini, mufasir bukanlah gurunya sendiri. Karena itu, kewajiban memahami diatur oleh apa yang menjadi isu utama di dalam teks itu sendiri. ${ }^{52}$ Bagi Ricour sebaliknya, ada hermeneutika di dalam Idea of Revelation. Dalam hal ini, menafsirkan berarti menjelaskan wujud di dunia yang mengemuka di depan teks. ${ }^{53}$ Dengan demikian, tugas hermeneutika filosofis bersikap sensitif terhadap semua jenis teks. Mengenai Al-Quran, teks diperlakukan sebagai sesuatu yang bergerak terus dan bukan hal yang bersifat statis (fixed thing), yakni sesuatu yang selalu berada selangkah di depan si penafsir, selalu terbuka untuk memasuki medan baru, dan selalu menyerukan penafsiran untuk memulai dengan yang baru. ${ }^{54}$ Bruns menyebukan bahwa yang paling penting dalam Al-Quran adalah bukan hanya yang berada di balik teks dalam bentuk makna azali (originating intention), namun juga apa yang berada di depan teks yakni ketika teks tersebut coba dipahami. Teks Al-Quran selalu berada dalam posisi sezaman dengan para pembaca maupun pendengarnya, yakni selalu berorientasi kepada zaman dan keadaan si penafsir. Ia membuka jalan bagi masa depan. $^{55}$

Ricouer menyatakan bahwa membaca Al-Quran dalam bahasa Inggris berarti tidak membaca Al-Quran. Orang harus membaca Al-Quran dalam bahasa Arab. ${ }^{56} \mathrm{Hal}$ ini tentu sangatlah berbeda dengan Bibel karena Bibel telah diterjemahkan ke dalam berbagai bahasa dan terjemahan ini

\footnotetext{
${ }^{52}$ Paul Ricoeur, "Preface to Bultmann," Essays on Biblical Interpretation, ed. Lewis S. Mudge (Philadelphia: Fortress Press, 1980), 64

${ }^{53}$ Paul Ricoeur, "The Hermeneutical Function of Distanciation," From Text to Action, trans. Kathleen Blamey and John B. Thompson (Evanston: Northwestern University Press, 2007), 86

${ }^{54}$ Gerald L. Bruns, Hermeneutics, Ancient and Modern, (New Haven: Yale University Press, 1992), 110-111

${ }^{55}$ Gerald L. Bruns, Hermeneutics, Ancient and Modern, 105-106

${ }^{56}$ Paul Ricoeur, "The 'Sacred' Text and the Community," Figuring the Sacred: Religion, Narrative and Imagination, trans. David Pellauer (Minneapolis: Fortress Press, 1995), 68.
}

umumnya menjadi acuan dalam memahami Bibel.

\section{KESIMPULAN}

Dari uraian di atas dapat disimpulkan bahwa penggunaan metode hermeneutika dalam memahami ayat-ayat Al-Quran nyaris bersfat elitis khususnya di kalangan para filsuf dan mufasir tertentu. Ruang gerak penggunaan hermeneutika dalam tafsir Al-Quran berada di dalam rentang kata yang tersurat (al-marjûh $\underline{\text { ) }}$ dan kemungkinan artinya yang bersifat tersirat (al-râjih $)$. Ada batasan yang jelas dalam menggunakan hermeneutika dalam menafsirkan ayat-ayat Al-Quran.

Penggunaan metode hermeneutika dalam memahami Bibel cenderung lebih luas dan, dalam pengertian tertentu, lebih bebas. Dalam konteks hubungan Bibel dengan ilmu pengetahuan, para pakar Bibel cenderung membandingkan secara diametral Bibel dan perkembangan ilmu pengetahuan untuk kemudian menjelaskan secara gamblang adanya ketidakselarasan di antara keduanya.

Salah satu faktor utama dalam hal ini adalah bahwa para penulis Bibel sering mengutip atau menyadur hikayat-hikayat kuno yang bersumber dari dunia peradaban lain.

\section{DAFTAR PUSTAKA}

Aththar, Nur al-Din, 'Ulûm al-Qur'ân alKarîm, Damaskus: Mathba'ah alShubul, 1993

Bruns, Gerald L., Hermeneutics, Ancient and Modern, New Haven: Yale University Press, 1992

Corliss, Richard L., "Schleiermacher's Hermeneutic and its Critics." Religious Studies. 29, 1993

al-Dzahabi, Muhammad Husayn, Al-Tafsîr wa al-Mufassirûn, (JeddaH: Wazarah Syu'un al-Islamiyyah wa al-Da'wah wa alIrsyad, 2010 
Al-Farabi, Arâ' Ahl al-Madînah alFâdhilah, Beirut: Dar al-Masyriq, 1986

Al-Ghazali, Tahâfut al-Falâsifah, tahkik Sulayman Dunya, Beirut: Dar alMa'arif, 1972 -----, Qânûn fi al-Ta'wîl, dita'liq dan ditahkik oleh Mahmud Bejou, Kairo: Dar al-Salam, 1993

Graham, Terry, "The Dual Aspect of Hermeneutics." Studies in Religion. 22(1), 1993

Grondin, Jean, Introduction to Philosophical Hermeneutics, New Haven: Yale University Press, 1994

Harbi, Muhammad, Ibn Taymiyyah wa Mawqifuhu min Ahamm al-Firaq wa al-Diyânât fì 'Ashrih, Beirut: 'Alam al-Kutub, 1987

Heidegger, Martin, Being and Time, trans. John Macquarrie and Edward Robinson San Francisco: Harper Collins Pub., 1962

Ibn Rusyd, Tahâfut al-Tahâfut, Kairo: Dar al-Ma'arif, 1963

Ibn Sina, Risâlah al-Adhhawiyyah fî amr al-ma'âd, Teheran: Syams al-Din Tabrizi, 1382

Klemm, David E., Hermeneutical Inquiry: Vol. 1, The Interpretation of Texts, Atlanta: Scholars Press, 1986

Mursyan, Salim, Al-Jânib al-Ilâhî 'inda Ibn Sînâ, Beirut: Dar Qutaybah, 1992

Palmer, Richard E., Hermeneutics: Interpretation Theory in Schleiermacher, Dilthey, Heidegger, and Gadamer, North Western University Press, Evanston, 1969

al-Qaththan, Mannâ', Mabâhits fì 'Ulûm alQur'ân, Kairo: Maktabah Wahbah, n.d

Ricoeur, Paul, Freud and Philosophy. An Essay on Interpretation, trans. Denis Savage (New Haven: Yale University Press, 1970
, "Preface to Bultmann," Essays on Biblical Interpretation, ed. Lewis S. Mudge, Philadelphia: Fortress Press, 1980

------------, "The Hermeneutical Function of Distanciation," From Text to Action, trans. Kathleen Blamey and John B. Thompson, Evanston: Northwestern University Press, 2007

------------, "The 'Sacred' Text and the Community," Figuring the Sacred: Religion, Narrative and Imagination, trans. David Pellauer, Minneapolis: Fortress Press, 1995

John R. Robert, Biblical Cosmology: The Implication for Bible Translation, Journal of Translation, Volume 9, Number 2, 2013

Schleiermacher, F.D.E. Hermeneutics: The Handwritten Manuscripts, Trans. James Duke and Jack Forstman. Ed. Heinz Kimmerle. (Missoula: Scholars Press, 1977

Sharif, M.M., History of Muslim Philosophy, Wiesbaden: Otto Harrassowitz, 1963

Shorter Oxford English Dictionary on Historical Principles, Vol. I, New York, 2002, 1231

Skehan, James W, Modern Science and the Book of Genesis, (Washington: National Science Teacher Association, 1986

Stadelmann, Luis I. J., The Hebrew conception of the world: A philological and literary study, Rome: Pontifical Biblical Institute, 1970

Stiver, Dan R., The Philosophy of Religious Language, Oxford: Blackwell Publishers Ltd., 1996

al-Suyuthi, Jalal al-Din, Al-Itqân fì 'Ûlûm al-Qur'ân, Kairo: Mushthafa al-Bab al-Halabi, 1935 